Journal of Zhejiang University-SCIENCE B (Biomedicine \& Biotechnology)
ISSN 1673-1581 (Print); ISSN 1862-1783 (Online)
www.zju.edu.cn/jzus; www.springerlink.com
E-mail: jzus@zju.edu.cn

\title{
Review:
}

\section{Deregulation of microRNA expression in thyroid tumors*}

\author{
Zi-ming YUAN, Zhi-li YANG, Qi ZHENG ${ }^{\dagger *}$ \\ (Department of General Surgery, Shanghai Sixth People's Hospital Affiliated to Shanghai Jiao Tong University School of Medicine, \\ Shanghai 200233, China) \\ †E-mail: zhengqi1957@aliyun.com
}

Received June 17, 2013; Revision accepted Nov. 11, 2013; Crosschecked Feb. 21, 2014

\begin{abstract}
MicroRNAs (miRNAs or miRs) are endogenous non-coding RNAs that negatively regulate gene expression by binding to the $3^{\prime}$ non-coding regions of target mRNAs, resulting in their cleavage or blocking their translation. miRNAs may have an impact on cell differentiation, proliferation, and survival, and their deregulation can be inclined to diseases and cancers, including thyroid tumors. The purpose of this review is to summarize the existing findings of deregulated miRNAs in different types of thyroid tumors and to exhibit their potential target genes, especially to demonstrate those involved in tumor invasion and metastasis. In addition, new findings of circulating miRNA expression profiles, single nucleotide polymorphism (SNP) in thyroid tumors, and the correlation of somatic mutations with deregulated miRNA expression in thyroid tumors were all included in this review.
\end{abstract}

Key words: MicroRNA, Target gene, Thyroid tumor, Single nucleotide polymorphism (SNP), Somatic mutation doi: 10.1631 jzus.B1300192

Document code: A

CLC number: R736.

\section{Introduction}

There are two distinct hormone-producing cell types composing the thyroid gland: follicular cells and parafollicular C cells (Pallante et al., 2010). More than $95 \%$ of thyroid tumors are derived from the follicular cells, while only 3\% are C-cell-derived carcinomas (Kondo et al., 2006). Thyroid nodules are common and their prevalence differs from $3 \%$ to $76 \%$, depending on the detection methods and the population evaluated (Ferraz et al., 2011). Most thyroid nodules are benign and just $5 \%$ are malignant (Gharib, 2004; Dean and Gharib, 2008). Benign nodules are principally represented as follicular thyroid adenomas (FTAs). The malignant nodules are carcinomas mostly and the thyroid carcinomas are one of the most common malignancies of the endocrine system (Mazeh, 2012). Depending on various histological and

\footnotetext{
${ }^{\ddagger}$ Corresponding author

" Project supported by the National Natural Science Foundation of China (No. 81272935)

(C) Zhejiang University and Springer-Verlag Berlin Heidelberg 2014
}

clinical features, the follicular cell-derived carcinomas are divided into well-differentiated thyroid carcinomas (WDTCs), poorly differentiated thyroid carcinomas (PDTCs), and undifferentiated thyroid carcinomas (Kondo et al., 2006). WDTCs include papillary thyroid carcinomas (PTCs) and follicular thyroid carcinomas (FTCs). Anaplastic thyroid cancers (ATCs) are highly undifferentiated and extremely aggressive (Yau et al., 2008; Braun and Hüttelmaier, 2011). PDTCs are medium carcinomas between WDTCs and ATCs. Medullary thyroid cancers (MTCs), the neuroendocrine tumor of the thyroid gland, are derived from parafollicular C cells (Pallante et al., 2010) and present as the hereditary form (HMTC; 25\%) and the sporadic form (SMTC; 75\%) (Abraham et al., 2011).

MicroRNAs (miRNAs or miRs) are small endogenous non-coding RNAs of 19-23 nucleotides that negatively regulate gene expressions by degrading mRNAs or blocking their translations (Ambros, 2004; Bartel, 2004). Productions and functions of miRNAs include multiple steps and require a large number of proteins (Nikiforova et al., 2009). They are transcribed from endogenous DNA by RNA polymerase II, and 
then processed from primary transcript (pri-miRNAs) to hairpin precursor (pre-miRNAs), which comprise two strands (Vriens et al., 2012). After that, they are exported by exportin-5 to the cytoplasm (Nikiforova et al., 2009; Marini et al., 2011). In the cytoplasm, pre-miRNAs undergo further processing by endonuclease Dicer and become mature miRNAs (Nikiforova et al., 2009; Frezzetti et al., 2011a; Marini et al., 2011). Mature miRNAs can bind to the 3' untranslated region (UTR) of mRNAs, resulting in blockage of translation or mRNA degradation depending on the degree of complementarity between miRNA and mRNA (Ambros, 2004; Bartel, 2004).

Agretti et al. (2012) reported that the number of known unique mature human miRNAs is 1921. The interaction between miRNA and mRNA is complex, partly because a single miRNA can target hundreds of different mRNA molecules (Ku and McManus, 2008) The miRNAs can influence cell differentiation, metabolism, and apoptosis, etc. (Cowland et al., 2007; Huang et al., 2010). It has been reported that the deregulation of miRNAs is involved in numerous cancers, including thyroid tumors (Mattie et al., 2006; Murakami et al., 2006; Chin et al., 2011). For example, five miRNAs (miR-146, -221, -222, -155, and -181a) were up-regulated in human PTCs as compared with normal human tissues (Menon and Khan, 2009); four miRNAs (miR-192, -197, -328, and -346) were overexpressed in the FTC as compared with the follicular adenoma (FA) (Weber et al., 2006); and significant decreases of miR-30d, $-125 \mathrm{~b},-26 \mathrm{a}$, and $-30 a-5 p$ were detected in ATCs in comparison to normal thyroid tissues (Visone et al., 2007). Thus, different tumor types have different miRNA expressions. Schwertheim et al. (2009) reported that the miRNA expression pattern in thyroid cancers depends on the cellular origin and tumor differentiation.

Recently, a lot of researches concerning miRNA alterations occurring in thyroid tumors have been performed. This improved knowledge has promoted the understanding about thyroid cancer etiology and has offered novel diagnostic and prognostic markers for thyroid tumors (Nikiforov and Nikiforova, 2011). To our knowledge, this was the first review focused on summarizing different molecular alterations in every type of thyroid tumor, besides that, the deregulated miRNAs on thyroid tumor invasion, the circulating miRNA expression profiles, and single nuc- leotide polymorphism (SNP) in thyroid tumors and the correlation of somatic mutations with deregulated miRNA expression in thyroid tumors were all included in this review. We hope to offer some improved and personalized diagnostic markers for thyroid tumors.

\section{2 miRNA expression profiles in papillary thyroid carcinomas (PTCs)}

Most studies analyzed miRNA expression profiles of PTCs using miRNA microarrays, and they revealed the up-regulation of seven miRNAs in PTCs compared with the normal thyroid, including miR-221, -222, -146, -21, -155, -181a, and -181b (Tetzlaff et al., 2007; Nikiforova et al., 2008). The up-regulation of miR-221, -222, and -181b showed the values of fold-change in some cases higher than 10 (Pallante et al., 2010). Sheu et al. (2010) showed a significant difference of the expression of miR-146b between PTCs and other benign thyroid lesions, such as multinodular goitre (MNG) and FA with foldchanges up to 90. Moreover, four different studies (He et al., 2005; Ricarte-Filho et al., 2009; Leone et al., 2011; Xiong et al., 2011) identified down-regulation of miRNAs in PTC in comparison to normal thyroid tissue. The different miRNA expression profiles in PTCs are shown in Table 1.

To understand how miRNAs play parts in neoplasia, many studies have been done to find the targets of miRNAs (Fig. 1). A computational search revealed that miR-146b-5p potentially binds to the 3' UTR of $S M A D 4$, an important member of the transforming growth factor- $\beta$ (TGF- $\beta$ ) signaling pathway, which is a negative regulator of thyroid follicular cell growth (Geraldo et al., 2012). It has also been reported that miR-146a and -146b can significantly down-regulate interleukin-1 (IL-1) receptor-associated kinase (IRAK1) and tumor necrosis factor (TNF) receptorassociated factor 6 (TRAFO), two key adaptor/scaffold proteins in the IL-1 and Toll-like receptor (TLR) signaling pathway, known to positively regulate nuclear factor- $\kappa \mathrm{B}(\mathrm{NF}-\kappa \mathrm{B})$ activity (Bhaumik et al., 2008). Other targets of miR-146a and $-146 \mathrm{~b}$ are chemokine receptor 4 (CXCR4) (Labbaye et al., 2008) and epidermal growth factor receptor $(E G F R)$ (Hurst et al., 2009), etc. 
Table 1 miRNAs aberrantly expressed in papillary thyroid carcinomas (PTCs)

\begin{tabular}{|c|c|c|c|c|c|c|}
\hline miRNA & $\begin{array}{l}\text { Specimen } \\
\text { type }\end{array}$ & $\begin{array}{l}\text { Detecting } \\
\text { technique }\end{array}$ & $\begin{array}{l}\text { Experimental } \\
\text { group }\end{array}$ & $\begin{array}{l}\text { Control } \\
\text { group }\end{array}$ & $\begin{array}{l}\text { Expression } \\
\text { profile }\end{array}$ & Reference \\
\hline $\begin{array}{l}\text { miR-146, -221, -222, -21, -220, } \\
\quad-181 \mathrm{a},-155\end{array}$ & $\begin{array}{l}\text { Snap-frozen } \\
\text { tissue }\end{array}$ & $\begin{array}{l}\text { miRNA } \\
\text { microarrays }\end{array}$ & Tumor tissue & $\begin{array}{l}\text { Normal thyroid } \\
\text { tissue }\end{array}$ & Up & $\begin{array}{l}\text { He et al., } \\
2005\end{array}$ \\
\hline $\begin{array}{l}\text { miR-187, }-221,-222,-146 b \\
\quad-155,-122 a,-31,-205,-224\end{array}$ & $\begin{array}{l}\text { Snap-frozen } \\
\text { tissue }\end{array}$ & RT-PCR & Tumor tissue & $\begin{array}{l}\text { Normal thyroid } \\
\text { tissue }\end{array}$ & Up & $\begin{array}{l}\text { Nikiforov } \\
\text { et al., } 2008\end{array}$ \\
\hline $\begin{array}{l}\operatorname{miR}-221,-222,-21,-31,-172 \\
\quad-34 a,-213,-181 b,-223,-224 \\
\quad-181 \mathrm{a}\end{array}$ & FFPE tissue & $\begin{array}{c}\text { miRNA } \\
\text { microarrays }\end{array}$ & Tumor tissue & $\begin{array}{l}\text { Benign prolifera- } \\
\text { tive multinodular } \\
\text { goiter }\end{array}$ & Up & $\begin{array}{c}\text { Tetzlaff } \\
\text { et al., } 2007\end{array}$ \\
\hline miR-146b, $-221,-222$ & FFPE tissue & qRT-PCR & Tumor tissue & $\begin{array}{l}\text { Follicular } \\
\text { adenoma }\end{array}$ & Up & $\begin{array}{l}\text { Chen et al., } \\
\quad 2008\end{array}$ \\
\hline $\begin{array}{l}\text { miR-218, }-300,-292,-345,-30 c \\
\quad-30 a-5 p,-19 b-1,2,-145 \mathrm{sh} \\
\quad-130 \mathrm{~b}\end{array}$ & FFPE tissue & $\begin{array}{l}\text { miRNA } \\
\text { microarrays }\end{array}$ & Tumor tissue & $\begin{array}{l}\text { Benign prolifera- } \\
\text { tive multinodular } \\
\text { goiter }\end{array}$ & Down & $\begin{array}{c}\text { Tetzlaff } \\
\text { et al., } 2007\end{array}$ \\
\hline miR-886-3p, miR-20a & $\begin{array}{l}\text { Snap-frozen } \\
\text { tissue }\end{array}$ & $\begin{array}{l}\text { miRNA } \\
\text { microarrays }\end{array}$ & Tumor tissue & $\begin{array}{l}\text { Normal thyroid } \\
\text { tissue }\end{array}$ & Down & $\begin{array}{c}\text { Xiong } \\
\text { et al., } 2011\end{array}$ \\
\hline $\operatorname{miR}-1$ & $\begin{array}{l}\text { Fresh thyroid } \\
\text { tissue sample }\end{array}$ & qRT-PCR & $\begin{array}{l}\text { Thyroid } \\
\text { adenomas and } \\
\text { carcinomas }\end{array}$ & $\begin{array}{l}\text { Normal thyroid } \\
\text { tissue }\end{array}$ & Down & $\begin{array}{c}\text { Leone } \\
\text { et al., } 2011\end{array}$ \\
\hline miR-26a-1, -345, -138, -219 & $\begin{array}{l}\text { Snap-frozen } \\
\text { tissue }\end{array}$ & $\begin{array}{l}\text { miRNA } \\
\text { microarrays }\end{array}$ & Tumor tissue & $\begin{array}{l}\text { Normal thyroid } \\
\text { tissue }\end{array}$ & Down & $\begin{array}{l}\text { He et al., } \\
2005\end{array}$ \\
\hline
\end{tabular}

FFPE tissue: formalin-fixed paraffin-embedded tissue; RT-PCR: reverse transcription-polymerase chain reaction; qRT-PCR: quantitative real-time polymerase chain reaction

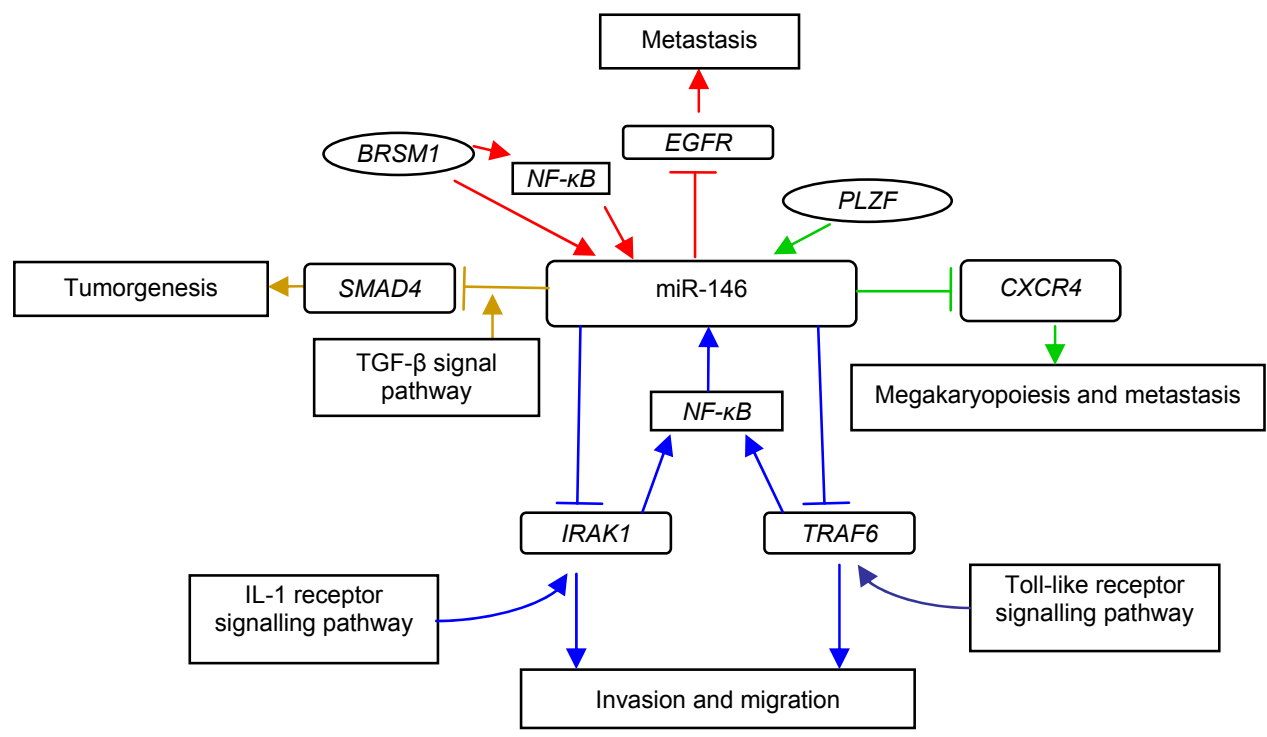

Fig. 1 Potential target genes and their working models of miR-146 in papillary thyroid carcinomas (PTCs) BRSM1: breast cancer metastasis suppressor-1; CXCR4: chemokine receptor 4; EGFR: epidermal growth factor receptor; $P L Z F$ : promyelocytic leukaemia zinc-finger; $N F-\kappa B$ : nuclear factor- $\mathrm{BB}$; TRAF6: tumor necrosis factor receptorassociated factor 6; IRAK1: interleukin-1 receptor-associated kinase

miR-221 and -222 are very similar in sequence, clustered on chromosome $\mathrm{X}$, and are likely transcribed as polycistron (Ciafrè et al., 2005). Several targets for the miR-221/222 cluster have been identified (Table 2). One of them is $c-K I T$, also called $C D 117$, a cytokine receptor for stem cell factors expressed on the surface of hematopoietic stem cells and other cell types (Felli et al., 2005). More recently, the 
$C D K N 1 B\left(p 27^{K i p l}\right)$ gene was identified as a target of miR-221 and -222 (Galardi et al., 2007; Visone et al., 2007). $p 27^{K i p l}$ is a member of the Cip/Kip family, which is related to cell differentiation, proliferation, migration, and apoptosis (Liu et al., 2012). Because $p 27^{K i p l}$ has a key role in cell cycle, particularly in the $\mathrm{G} 1 / \mathrm{S}$ transition, the enforced expression of miR-221 and -222 can stimulate thyroid carcinoma cells to break the G1/S block (Pallante et al., 2010). Other studies have also shown that miR-221 can target $C D K N 1 C / p 57$ that has a critical role in the cell cycle control (Garofalo et al., 2008).

\section{3 miRNA expression in follicular thyroid carcinomas (FTCs)}

Follicular adenoma and follicular carcinoma of the thyroid gland with microfollicular architecture are lined by cuboidal epithelial cells (McHenry and Phitayakorn, 2011). Because of the significant similarities at morphology and molecule among FTCs and FTAs (Braun and Hüttelmaier, 2011), miRNAs may become valuable markers to distinguish these tumors. As shown in Table 3, the most highly up-regulated miRNAs in conventional FTCs were miR-187, -224, $-155,-222$, and -221 , and those in oncocytic variants were miR-187, $-221,-339,-183,-222$, and -197 , whereas the most highly up-regulated miRNAs in conventional FTAs were miR-339, -224, -205, -210, $-190,-328$, and -342 , and those in oncocytic variants were miR-31, -339, -183, -221, -224, and -203 (Nikiforova et al., 2008). Weber et al. (2006) revealed four miRNAs (miR-346, -328, -192, and -197) moderately up-regulated by $1.34-1.82$-fold in FTCs when compared to FTAs.

The potential target genes of miR-197 and -346 are reported as extracellular matrix (ECM) components epidermal growth factor-containing fibulin-like extracellular matrix protein 2 (EFEMP2), tetraspanin 3 (TSPAN3), and activin A receptor type 1 (ACVR1). EFEMP2 seems to have tumor suppressor functions (Gallagher et al., 2001; Argraves et al., 2003) and was reported to be overexpressed in colon carcinomas but down-expressed in prostate cancer (Wlazlinski et al., 2007). TSPAN3 belongs to the tetraspan superfamily, whose members are inversely correlated with the metastatic potential in melanoma (Boucheix et al., 2001), and ACVR1 is involved in the control of cell growth (Schulte et al., 2001). Colamaio et al. (2011) found that the miR-191 is down-regulated in FA, FTC, and follicular variant of PTC and identified CDK6, a serine-threonine kinase involved in the control of cell cycle, as a novel target of miR-191.

Table 2 Potential target genes of miR-221/222 in papillary thyroid carcinomas (PTCs)

\begin{tabular}{llll}
\hline \multicolumn{1}{c}{ miRNA } & Potential target gene & Potential function & \multicolumn{1}{c}{ Reference } \\
\hline miR-221/222 & $c-K I T(C D 117)$ & Stem cell factor & Felli et al., 2005 \\
miR-221/222 & $C D K N 1 B\left(p 27^{K i p l}\right)$ & Cell cycle & Pallante et al., 2010 \\
miR-221 & $C D K N 1 C / p 57$ & Cell cycle control & Garofalo et al., 2008 \\
\hline
\end{tabular}

Table 3 miRNAs aberrantly expressed in follicular thyroid carcinomas (FTCs)

\begin{tabular}{|c|c|c|c|c|c|c|c|}
\hline $\begin{array}{c}\text { Tumor } \\
\text { histotype }\end{array}$ & miRNA & $\begin{array}{c}\text { Specimen } \\
\text { type }\end{array}$ & $\begin{array}{l}\text { Detecting } \\
\text { technique }\end{array}$ & $\begin{array}{l}\text { Experimental } \\
\text { group }\end{array}$ & $\begin{array}{l}\text { Control } \\
\text { group }\end{array}$ & $\begin{array}{l}\text { Expression } \\
\text { rofile }\end{array}$ & Reference \\
\hline \multicolumn{8}{|c|}{ Follicular thyroid adenoma (FTA) } \\
\hline $\begin{array}{l}\text { Conventional } \\
\text { type } \\
\text { Oncocytic } \\
\text { type }\end{array}$ & $\begin{array}{c}\operatorname{miR}-339,-224,-205,-210 \\
-190,-328,-342 \\
\operatorname{miR}-31,-339,-183 \\
-221,-224 a,-203\end{array}$ & $\begin{array}{l}\text { Snap- } \\
\text { frozen } \\
\text { tissue }\end{array}$ & RT-PCR & $\begin{array}{l}\text { Tumor } \\
\text { tissue }\end{array}$ & $\begin{array}{l}\text { Normal } \\
\text { thyroid } \\
\text { tissue }\end{array}$ & Up & $\begin{array}{l}\text { Nikiforova } \\
\text { et al., } 2008\end{array}$ \\
\hline \multicolumn{8}{|c|}{ Follicular thyroid carcinoma (FTC) } \\
\hline $\begin{array}{l}\text { Conventional } \\
\text { type } \\
\text { Oncocytic } \\
\text { type }\end{array}$ & $\begin{array}{c}\operatorname{miR}-187,-224,-155, \\
-222,-221,-146 b \\
\operatorname{miR}-187,-221,-339 \\
-183,-222,-197\end{array}$ & $\begin{array}{l}\text { Snap- } \\
\text { frozen } \\
\text { tissue }\end{array}$ & RT-PCR & $\begin{array}{l}\text { Tumor } \\
\text { tissue }\end{array}$ & $\begin{array}{l}\text { Normal } \\
\text { thyroid } \\
\text { tissue }\end{array}$ & Up & $\begin{array}{l}\text { Nikiforova } \\
\text { et al., } 2008\end{array}$ \\
\hline
\end{tabular}




\section{4 miRNA expression in poorly differentiated thyroid carcinomas (PDTCs)}

PDTC is a follicular cell derived from malignant neoplasm, it is intermediate between differentiated thyroid carcinomas and ATCs through morphologically and biologically (Schwertheim et al., 2009). Aiming to distinguish the miRNA expression in PDTCs, Schwertheim et al. (2009) investigated the expression levels of two distinct sets of miRNAs in 15 PDTCs. The results showed that the 'set 1' (miR-146b, $-181 b,-21,-221$, and -222) expressions were slightly increased in PDTCs, while they were significantly up-regulated in PTCs and ATCs when compared to normal thyroid tissue. As to 'set 2' miRNAs (miR-30d, $-125 b,-26 a,-30 a-5 p$, and -let-7c), which are expressed at low levels in PDTCs and ATCs but are significantly up-regulated in PTCs. The integrated results were useful to discriminate PDTCs from PTCs and ATCs. Nikiforova et al. (2008) investigated that there were ten miRNAs overexpressed in PDTCs relative to normal thyroid tissues, and further seven miRNAs (miR-187, -221, -129, -222, -146b, -339, and -183) significantly overexpressed in PDTCs as compared with hyperplastic nodules. According to Chiappetta et al. (2008), high-mobility group AT-hook 2 (HMGA2), which correlates with malignancy in human thyroid neoplasias, was a possible target of miRNA-125b and -26 .

\section{5 miRNA expression in anaplastic thyroid cancers (ATCs)}

As far as ATCs are concerned, the most striking difference between ATCs and other thyroid carcinomas derived from follicular cells is that they displayed a significantly decreased expression of various miRNAs (Visone et al., 2007; Schwertheim et al., 2009; Braun et al., 2010). The most significantly decreased miRNAs in expression were miR-30d, -125b, and -26a (Visone et al., 2007; Schwertheim et al., 2009). Contrary to the expression in PTCs, miR-138 was found to be severely decreased in ATC samples as well as in ATC-derived cell lines
(Mitomo et al., 2008; Takakura et al., 2008; Braun et al., 2010). Braun et al. (2010) identified two significantly reduced miRNA families that can certainly distinguish ATCs from PTCs and FTCs: miR-200 and miR-30. While recent studies have also revealed up-regulation of several miRNAs in ATCs. Nikiforova et al. (2008) revealed that miR-302c, -205 , and -137 were overexpressed in ATCs when compared to hyperplastic nodules. Visone et al. (2007) observed four miRNAs (miR-222, -198, -let-7f-1, and -let-7a-2) elevated in ATCs by comparing them with nontransformed thyroid tissues. Takakura et al. (2008) reported that the miR-17-92 cluster of seven miRNAs (miR-17-5p, -17-3p, -18a, -19a, -20a, -19b, and -92-1) as well as miR-106a and -106b were overexpressed in ATC cell lines. miR-17-3p and -17-5p displayed overexpression also in human ATC samples when compared to normal tissues. Other studies also found that miR-21, $-146 \mathrm{~b},-221$, and -222 were overexpressed in ATCs (Mitomo et al., 2008; Nikiforova et al., 2008; Frezzetti et al., 2011b). These findings are summarized in Table 4.

The research concerning the targets of the miRNAs of ATCs (Table 5) reveal that the potential target gene of miR-30a may be Beclin 1, which is a key autophagy-promoting gene that plays a critical role in regulation of cell death and survival of several cell types (Zhu et al., 2009). Kota et al. (2009) demonstrated that cyclins D2 and E2 are potential target genes of miR-26a in liver cancer cells. A potential target of miR-138 is the human telomerase reverse transcriptase ( $h T E R T)$, whose overexpression has been associated with dedifferentiation, tumor stage, and increased metastatic and invasive phenotypes (Mitomo et al., 2008). The miR-17 family has been demonstrated to modulate the fibroblast growth factor $10(F G F 10)$ and fibroblast growth factor receptor $2 \mathrm{~b}(F G F R 2 b)$, which can modulate epithelial bud morphogenesis in response to FGF10 signaling (Carraro et al., 2009). More recently, Esposito et al. (2012) reported that miR-25 and -30d putatively targeted the polycomb protein enhancer of zeste 2 $(E Z H 2)$, which has oncogenic activity and was drastically up-regulated in ATCs but not in the differentiated ones. 
Table 4 miRNAs aberrantly expressed in anaplastic thyroid cancers (ATCs)

\begin{tabular}{|c|c|c|c|c|c|c|}
\hline miRNA & $\begin{array}{l}\text { Specimen } \\
\text { type }\end{array}$ & $\begin{array}{l}\text { Detecting } \\
\text { technique }\end{array}$ & $\begin{array}{l}\text { Experimental } \\
\text { group }\end{array}$ & $\begin{array}{l}\text { Control } \\
\text { group }\end{array}$ & $\begin{array}{l}\text { Expression } \\
\text { profile }\end{array}$ & Reference \\
\hline $\operatorname{miR}-30 d,-125 b$ & $\begin{array}{l}\text { Thyroid } \\
\text { sample }\end{array}$ & $\begin{array}{l}\text { miRNA } \\
\text { microarrays }\end{array}$ & ATC & $\begin{array}{c}\text { Normal thyroid } \\
\text { tissue }\end{array}$ & Down & $\begin{array}{l}\text { Visone } \\
\text { et al., } 2007\end{array}$ \\
\hline miR-138 & $\begin{array}{l}\text { Snap-frozen } \\
\text { tissue }\end{array}$ & RT-PCR & ATC & $\begin{array}{l}\text { Papillary thyroid } \\
\text { carcinoma }\end{array}$ & Down & $\begin{array}{l}\text { Mitomo } \\
\text { et al., } 2008\end{array}$ \\
\hline $\begin{array}{l}\operatorname{miR}-302 \mathrm{c},-205,-137,-187,-214 \\
\quad-155,-224,-222,-221\end{array}$ & $\begin{array}{l}\text { Snap-frozen } \\
\text { tissue }\end{array}$ & RT-PCR & Tumor tissue & $\begin{array}{c}\text { Normal thyroid } \\
\text { tissue }\end{array}$ & Up & $\begin{array}{l}\text { Nikiforova } \\
\text { et al., } 2008\end{array}$ \\
\hline $\begin{array}{l}\text { miR-222, -198, -let-7f-1, } \\
\quad \text {-let-7a-2 }\end{array}$ & $\begin{array}{l}\text { Thyroid } \\
\text { sample }\end{array}$ & $\begin{array}{l}\text { miRNA } \\
\text { microarrays }\end{array}$ & ATC & $\begin{array}{c}\text { Normal thyroid } \\
\text { tissue }\end{array}$ & Up & $\begin{array}{c}\text { Visone } \\
\text { et al., } 2007\end{array}$ \\
\hline $\begin{array}{c}\operatorname{miR}-192,-196 a,-194,-429 \\
-200 b,-7,-10 a,-16\end{array}$ & Cell line & $\begin{array}{c}\text { miRNA } \\
\text { microarrays }\end{array}$ & $\begin{array}{l}\text { ATC cell } \\
\text { lines ARO }\end{array}$ & PT & Up & $\begin{array}{l}\text { Takakura } \\
\text { et al., } 2008\end{array}$ \\
\hline
\end{tabular}

PT: cells isolated from thyroid tissues of patients with Graves' disease

Table 5 Potential target genes of unregulated miRNAs of anaplastic thyroid cancers (ATCs)

\begin{tabular}{|c|c|c|c|}
\hline miRNA & Potential target gene & Potential function & Reference \\
\hline miR-30a & Beclin 1 & Regulate cell death and survival of various cell types & Zhu et al., 2009 \\
\hline $\operatorname{miR}-26 a$ & Cyclins D2 and E2 & Cell cycle arrest & Kota et al., 2009 \\
\hline $\operatorname{miR}-138$ & hTERT & $\begin{array}{l}\text { Dedifferentiation, tumor stage, and increased } \\
\text { metastatic and invasive phenotypes }\end{array}$ & Mitomo et al., 2008 \\
\hline miR-17 family & STAT3 and MAPK14 & Modulate epithelial bud morphogenesis & Carraro et al., 2009 \\
\hline miR-25, -30d & $\mathrm{EZH} 2$ & Oncogenic activity & Esposito et al., 2012 \\
\hline
\end{tabular}

\section{6 miRNA expression in medullary thyroid cancers (MTCs)}

Few studies have been conducted to investigate the function of miRNAs in MTC pathogenesis. Nikiforova et al. (2008) revealed up-regulation of miR-323, -370, -129, -137, -10a, -124a, -224, -127, -9, and -154 , which showed a value of fold-change from 142.2 to 32.3 in MTCs compared to normal thyroid tissues (Table 6). A study conducted by Abraham et al. (2011) in a series of 19 patients including 12 SMTC and 7 HMTC and their results, which were further validated by quantitative polymerase chain reaction (qPCR), indicated that miR-183 and miR-375 were overexpressed, whereas miR-9* was down-expressed in SMTC compared with HMTC. Mian et al. (2012) verified the overexpression of nine miRNAs (miR-21, $-127,-154,-224,-323,-370,-9 *,-183$, and -375$)$ by quantitative real-time PCR (qRT-PCR) in MTC patients. To further study the potential target genes of miR-21, they analyzed the immunohistochemical expression of programmed cell death 4 (PDCD4) and found that the $P D C D 4$ expression was significantly down-regulated in MTC samples in line with the up-regulation of miR-21.

\section{Association between miRNA expression and thyroid tumor invasion}

The migration and metastasis of cancer cells take place in three steps: adherence, degradation, and movement (Gao et al., 2010). In order to invade the circulatory and lymphatic systems to get metastasis, the tumor cells must initiate and completely come through all of these steps (Ponta et al., 2001). Gao et al. (2010) have done experiments between highly metastatic PTC cell lines and common human PTC cell lines to illustrate the relationship between deregulated miRNAs and metastasis of PTCs. The results showed that 11 miRNAs were differentially expressed in the metastatic and control cell lines. Among the 11 miRNAs, 9 (let-7b, miR-222, -106, -193, -34, -29, $-26 \mathrm{a},-15 \mathrm{a}$, and -200 ) were reported to have an important role in tumor metastasis (Nikiforova et al., 2008) or epithelial-mesenchymal transition (EMT) 
Table 6 miRNAs aberrantly expressed in medullary thyroid cancers (MTCs)

\begin{tabular}{|c|c|c|c|c|c|c|}
\hline miRNA & $\begin{array}{l}\text { Specimen } \\
\text { type }\end{array}$ & $\begin{array}{l}\text { Detecting } \\
\text { technique }\end{array}$ & $\begin{array}{l}\text { Experimental } \\
\text { group }\end{array}$ & $\begin{array}{l}\text { Control } \\
\text { group }\end{array}$ & $\begin{array}{l}\text { Expression } \\
\text { profile }\end{array}$ & Reference \\
\hline $\begin{array}{c}\operatorname{miR}-323,-370,-129,-137,-10 a \\
-124 a,-224,-127,-9,-154\end{array}$ & $\begin{array}{l}\text { Snap-frozen } \\
\text { tissue }\end{array}$ & RT-PCR & Tumor tissue & $\begin{array}{c}\text { Normal thyroid } \\
\text { tissue }\end{array}$ & Up & $\begin{array}{l}\text { Nikiforova } \\
\text { et al., } 2008\end{array}$ \\
\hline miR-183, -375 & $\begin{array}{l}\text { Snap-frozen } \\
\text { tissue }\end{array}$ & qPCR & SMTC & HMTC & Up & $\begin{array}{l}\text { Abraham } \\
\text { et al., } 2011\end{array}$ \\
\hline miR-9* & $\begin{array}{l}\text { Snap-frozen } \\
\text { tissue }\end{array}$ & qPCR & SMTC & HMTC & Down & $\begin{array}{l}\text { Abraham } \\
\text { et al., } 2011\end{array}$ \\
\hline $\begin{array}{l}\operatorname{miR}-21,-127,-154,-224,-323, \\
\quad-370,-9^{*},-183,-375\end{array}$ & $\begin{array}{l}\text { Snap-frozen } \\
\text { tissue }\end{array}$ & qRT-PCR & MTC & $\begin{array}{l}\text { Normal thyroid } \\
\text { tissue }\end{array}$ & Up & $\begin{array}{l}\text { Mian et al., } \\
\quad 2012\end{array}$ \\
\hline
\end{tabular}

HMTC: hereditary medullary thyroid cancer; SMTC: sporadic medullary thyroid cancer

(Gregory et al., 2008; Korpal and Kang, 2008; Gebeshuber et al., 2009), while another two miRNAs (miR-199b and -16) were respectively involved in the tumor stem cell fate determination and apoptosis (Garzia et al., 2009; Guo et al., 2009). In another study, Yip et al. (2011) observed that miR-146b, -221, -222 , and -155 were enhanced by up-regulation, while miR-1, $-34 b,-130 b$, and -138 were significantly down-regulated in aggressive tumors compared with non-aggressive PTCs. miR-183 and miR-375, which can predict lateral lymph node metastases in MTC, are associated with residual disease, metastases, and mortality (Abraham et al., 2011). While high miR-224 levels have been associated with lower stages of diagnosis, and none lymph node metastases or a biochemically free status was at the terminal of the follow-up in MTCs (Mian et al., 2012).

Because miRNAs play their functions by influencing their target genes, the metastasis-related genes have become the focus of the ongoing research. One study about miR-146b was conducted in vitro in a highly metastatic human breast cancer cell line (Hurst et al., 2009). The breast cancer metastasis suppressor 1 (BRSM1) up-regulates miR-146a and $-146 b$, which can suppress breast cancer metastasis since they are likely to reduce the signaling through the NF- $\kappa$ B pathway (Fig. 1). TSPAN3, the potential target of miR-197, which belongs to the tetraspan superfamily, was inversely correlated with the metastatic potential in melanoma (Argraves et al., 2003; Colamaio et al., 2011). One potential target gene of miR-1 is CXCR4, which is often overexpressed in PTCs and plays a major role in lymph node metastasis from a primary tumor (Castellone et al., 2004).

\section{Circulating miRNA expression profiles in thyroid tumor}

There have previously been lots of diagnostic and/or prognostic markers for thyroid tumor tissues or cells from fine-needle aspiration (FNA). Yu et al. (2012) stuided the relationship between genome-wide serum miRNA expression profiles and thyroid tumors using Solexa sequencing followed by extensive qRT-PCR validation in 245 subjects (106 PTCs, 95 benign nodules, and 44 healthy controls). The results suggested that the expressions of serum let-7e, miR-151-5p, and miR-222 were significantly increased in the PTC cases compared to the benign cases and healthy controls. Receiver operating characteristic curve analyses indicated that these three miRNAs had a high diagnostic sensitivity and specificity for PTCs and their expression levels were well-correlated with certain clinicopathological features, such as nodal status, tumor size, multifocal lesion status, and the tumor-node-metastasis stage. Besides, one important thing of the serum miRNAs profiles may be their convenient and minimally invasive characters as novel diagnostic markers for PTC, though large-scale and multi-center studies are needed.

\section{Contribution of single nucleotide poly- morphism (SNP) to thyroid tumors}

SNPs are the most common type of genetic variation which can lead to alterations in miRNA expression resulting in diverse functional consequences (Wang et al., 2012), such as population 
diversity, disease susceptibility, and individual response to medicine (Shastry, 2009). SNPs located in miRNA-related regions including primary and precursor miRNA sequences, seed sequence of miRNAs, miRNA processing genes, and 3' UTR of target genes, can diversify miRNA production and the affinity and specificity between miRNAs and mRNAs (Landi et al., 2012). Since a specific miRNA has the ability to regulate hundreds of target mRNAs, SNPs in miRNAs may produce varied functions (Wang et al., 2012). Here, miR-146a rs2910164 was one of the most common studied miRNA polymorphisms (Yue et al., 2011; Zhou et al., 2011).

Human miR-146 comes in two distinct forms: miR-146a encoded on chromosome $5 \mathrm{q} 33$ and miR-146b encoded on chromosome 10q24 (Jazdzewski et al., 2008). The two related miR-146s are differentially regulated, with miR-146a strongly induced by lipopolysaccharide and regulated by NF- $\mathrm{KB}$ (Taganov et al., 2006; Jazdzewski et al., 2008). The miR-146a rs2910164 polymorphism is located at a position +60 relative to the first nucleotide of pre-miR-146a. The $\mathrm{G}$ to $\mathrm{C}$ change in the passenger strand results in a decreased mature miR-146a (Yue et al., 2011). Jazdzewski et al. (2008) found that the miR-146a rs2910164 CC genotype in pre-miR-146a was associated with a reduced production of mature miR-146a and contributed to a genetic predisposition to PTC. Because miR-146a is known to be an NF- $\mathrm{kB}-$ dependent gene (Taganov et al., 2006; Cameron et al., 2008) and can inhibit the downstream target genes, TRAF6 and IRAK1, two key downstream adapter molecules of the TLR and cytokine receptors, Jazdzewski et al. (2008) speculated that the SNP can affect the negative feedback regulation loop in TLR and cytokine signaling pathway.

\section{Correlation of somatic mutations with deregulated miRNA expression in thyroid tumors}

Recent studies have suggested that genetic alterations in oncogenes may be of clinical use in thyroid neoplasms. The most common genetic alterations occurring in thyroid cancers are related with signal transduction pathways, including tyrosine kinase receptors $[R E T / P T C$ and neurotrophic tyrosine receptor kinase $(N T R K)$ ], signaling proteins (BRAF and $R A S)$, and nuclear proteins [paired box $(P A X) 8$ and peroxisome proliferator-activated receptor $\gamma(P P A R-\gamma)]$ (Vriens et al., 2009). These genetic changes are always mutually exclusive (Shibru et al., 2008) and have something to show about the deregulated miRNAs.

Mutation of the $B R A F$ gene is most prominent in PTCs with an appearance up to $50 \%$ (Kondo et al., 2006; Pallante et al., 2010). The BRAF mutation in primary PTC is a T-A substitution at nucleotide 1799 in exon 15, which results in a change from valine acid to glutamic acid at codon 600 (V600E) of the BRAF protein (Wellbrock et al., 2004; Wojciechowska and Lewinski, 2006; Mitsiades et al., 2007), resulting in activation of the mitogen-activated protein kinase (MAPK) pathway (Wan et al., 2004; Knauf et al., 2005). The presence of a BRAF mutation has been associated with the poorer prognosis in PTC patients, such as an advanced stage at diagnosis, extrathyroidal extension, and lymph node metastasis (Xing, 2007; Elisei et al., 2008a; Yip et al., 2009). Recently, studies aiming to show an association between $B R A F$ positivity and miR-146b in aggressive PTCs (Chou et al., 2010; Yip et al., 2011) found that miR-146b was significantly overexpressed in $B R A F$-positive PTCs with aggressive tumor behaviors. Mutations of the $R A S$ genes ( $K-R A S, H-R A S$, and $N-R A S$ presented in codons 12,13 , and 61 , respectively) were found in all thyroid cancers. The mutation frequencies are $10 \%-$ $20 \%$ in PTCs, $20 \%-40 \%$ in FTAs, $40 \%-50 \%$ in FTCs, $20 \%-55 \%$ in PDTCs, and $20 \%-60 \%$ in ATCs (Kondo et al., 2006; Pallante et al., 2010). RAS proteins are plasma membrane GTPases activated by growth factor receptors, non-receptor tyrosine kinases, and G-protein-coupled receptors (Fagin and Mitsiades, 2008). It was reported that $R A S$-positive PTCs expressed the highest amount of miR-146 (Nikiforova et al., 2008). RET rearrangement is caused by interchromosomal translocations and there have been reported a total of 15 different RET/PTC rearrangements. The most widely occurring are RET/PTC1 (RET kinase fused with $\mathrm{H} 4$ gene) and RET/PTC3 (RET kinase fused with $R F G$ gene) (Pallante et al., 
2010). Nikiforova et al. (2008) reported that miR-187 was expressed at high levels in PTCs harboring RET/PTC rearrangements, while miR-221 and -222 were found at the highest level in BRAF- and $R A S$-positive PTCs. The frequencies of RET rearrangements are lower in PTCs $(20 \%-40 \%)$ and PDTCs $(\sim 10 \%)$ (Vriens et al., 2009; Braun and Hüttelmaier, 2011). However, it has been documented that the frequency of RET rearrangement in MTC cases is in the range of $40 \%-50 \%$ (Elisei et al., 2008b). And significantly lower miR-127 levels were observed in SMTC carrying somatic RET mutations in comparison to SMTC carrying a wild-type RET (Mian et al., 2012).

\section{Summary}

MicroRNAs constitute a recently identified class of small endogenous noncoding RNAs that act as negative regulators of the protein-coding gene expression and may impact cell differentiation, proliferation, and survival, i.e., all fundamental cellular processes implicated in carcinogenesis. The miRNA expressiones are deregulated in many types of human cancers, including thyroid cancer. There are many types of thyroid carcinomas, such as PTCs, FTCs, ATCs, and MTCs. Several studies have shown the deregulation of miRNA expression in human thyroid carcinomas, such as miR-146, -221, -222, -155, and -181a up-regulated in human PTC as compared with normal human tissue; miR-192, -197, -328, and -346 overexpressed in FTC as compared with Fas; and, miR-17-92 cluster overexpressed in ATC cell lines as compared with normal tissues and follicular carcinoma cell lines. Among these deregulated miRNAs, some have relevance with the thyroid tumor invasion and metastasis. Besides, circulating miRNA (serum or peripheral blood miRNAs) expression profiles in thyroid tumor have been studied recently, as novel diagnostic and/or prognostic tools. SNPs, as the most common type of genetic variation, which exist in miRNA genes, can lead to diverse functional consequences, including thyroid carcinomas. And the somatic mutations have relevance with the deregulated miRNA expression in thyroid tumors. For example,
miR-146b was significantly overexpressed in the $B R A F$-positive PTC that also had aggressive tumor behaviors and it was reported that $R A S$-positive PTCs expressed the highest amount of miR-146.

In this review, the documented miRNA profiles and their potential target genes in each type of thyroid tumor were summarized. We also recorded the latest researches on circulating miRNA expression profiles in thyroid tumors and the contribution of SNPs to thyroid tumors, in order to contribute to the search for thyroid tumor diagnosis and treatment.

\section{Compliance with ethics guidelines}

Zi-ming YUAN, Zhi-li YANG, and Qi ZHENG declare that they have no conflict of interest.

This article does not contain any studies with human or animal subjects performed by any of the authors.

\section{References}

Abraham, D., Jackson, N., Gundara, J.S., et al., 2011. MicroRNA profiling of sporadic and hereditary medullary thyroid cancer identifies predictors of nodal metastasis, prognosis, and potential therapeutic targets. Clin. Cancer Res., 17(14):4772-4781. [doi:10.1158/1078-0432. CCR-11-0242]

Agretti, P., Ferrarini, E., Rago, T., et al., 2012. MicroRNA expression profile helps to distinguish benign nodules from papillary thyroid carcinomas starting from cells of fine-needle aspiration. Eur. J. Endocrinol., 167(3): 393-400. [doi:10.1530/EJE-12-0400]

Ambros, V., 2004. The functions of animal microRNAs. $\mathrm{Na}$ ture, 431(7006):350-355. [doi:10.1038/nature02871]

Argraves, W.S., Greene, L.M., Cooley, M.A., et al., 2003. Fibulins: physiological and disease perspectives. EMBO Rep., 4(12):1127-1131. [doi:10.1038/sj.embor.7400033]

Bartel, D.P., 2004. MicroRNAs: genomics, biogenesis, mechanism, and function. Cell, 116(2):281-297. [doi:10. 1016/S0092-8674(04)00045-5]

Bhaumik, D., Scott, G.K., Schokrpur, S., et al., 2008. Expression of microRNA-146 suppresses NF- $\mathrm{KB}$ activity with reduction of metastatic potential in breast cancer cells. Oncogene, 27(42):5643-5647. [doi:10.1038/onc.2008. 171]

Boucheix, C., Duc, G.H., Jasmin, C., et al., 2001. Tetraspanins and malignancy. Expert Rev. Mol. Med., 3(4):1-17. [doi:10.1017/S1462399401002381]

Braun, J., Hüttelmaier, S., 2011. Pathogenic mechanisms of deregulated microRNA expression in thyroid carcinomas of follicular origin. Thyroid Res., 4(Suppl. 1):S1. [doi:10. 1186/1756-6614-4-S1-S1] 
Braun, J., Hoang-Vu, C., Dralle, H., et al., 2010. Downregulation of microRNAs directs the EMT and invasive potential of anaplastic thyroid carcinomas. Oncogene, 29(29):4237-4244. [doi:10.1038/onc.2010.169]

Cameron, J.E., Yin, Q., Fewell, C., et al., 2008. Epstein-Barr virus latent membrane protein 1 induces cellular microRNA miR-146a, a modulator of lymphocyte signaling pathways. J. Virol., 82(4):1946-1958. [doi:10.1128/JVI. 02136-07]

Carraro, G., El-Hashash, A., Guidolin, D., et al., 2009. miR-17 family of microRNAs controls FGF10-mediated embryonic lung epithelial branching morphogenesis through MAPK14 and STAT3 regulation of E-cadherin distribution. Dev. Biol., 333(2):238-250. [doi:10.1016/j.ydbio.2009. 06.020]

Castellone, M.D., Guarino, V., de Falco, V., et al., 2004. Functional expression of the $C X C R 4$ chemokine receptor is induced by RET/PTC oncogenes and is a common event in human papillary thyroid carcinomas. Oncogene, 23(35):5958-5967. [doi:10.1038/sj.onc.1207790]

Chen, Y.T., Kitabayashi, N., Zhou, X.K., et al., 2008. MicroRNA analysis as a potential diagnostic tool for papillary thyroid carcinoma. Mod. Pathol., 21(9): 1139-1146. [doi:10.1038/modpathol.2008.105]

Chiappetta, G., Ferraro, A., Vuttariello, E., et al., 2008. HMGA2 mRNA expression correlates with the malignant phenotypein human thyroid neoplasias. Eur. J. Cancer, 44(7):1015-1021. [doi:10.1016/j.ejca.2008.02.039]

Chin, L., Hahn, W.C., Getz, G., et al., 2011. Making sense of cancer genomic data. Genes Dev., 25(6):534-555. [doi:10. 1101/gad.2017311]

Chou, C.K., Chen, R.F., Chou, F.F., et al., 2010. miR-146b is highly expressed in adult papillary thyroid carcinomas with high risk features including extrathyroidal invasion and the $B R A F^{\mathrm{V} 600 \mathrm{E}}$ mutation. Thyroid, 20(5):489-494. [doi:10.1089/thy.2009.0027]

Ciafrè, S.A., Galardi, S., Mangiola, A., et al., 2005. Extensive modulation of a set of microRNAs in primary glioblastoma. Biochem. Biopys. Res. Commun., 334(4): 1351-1358. [doi:10.1016/j.bbrc.2005.07.030]

Colamaio, M., Borbone, E., Russo, L., et al., 2011. miR-191 down-regulation plays a role in thyroid follicular tumors through CDK6 targeting. J. Clin. Endocrinol. Metab., 96(12):E1915-E1924. [doi:10.1210/jc.2011-0408]

Cowland, J.B., Hother, C., Grønbaek, K., 2007. MicroRNAs and cancer. APMIS, 115(10):1090-1106. [doi:10.1111/j. 1600-0463.2007.apm_775.xml.x]

Dean, D.S., Gharib, H., 2008. Epidemiology of thyroid nodules. Best Pract. Res. Clin. Endocrinol. Metab., 22(6): 901-911. [doi:10.1016/j.beem.2008.09.019]

Elisei, R., Ugolini, C., Viola, D., et al., 2008a. $B R A F^{\mathrm{V} 600 \mathrm{E}}$ mutation and outcome of patients with papillary thyroid carcinoma: a 15-year median follow-up study. J. Clin. Endocrinol. Metab., 93(10):3943-3949. [doi:10.1210/jc.
2008-0607]

Elisei, R., Cosci, B., Romei, C., et al., 2008b. Prognostic significance of somatic RET oncogene mutations in sporadic medullary thyroid cancer: a 10-year follow-up study. J. Clin. Endocrinol. Metab., 93(3):682-687. [doi:10. 1210/jc.2007-1714]

Esposito, F., Tornincasa, M., Pallante, P., et al., 2012. Down-regulation of the miR-25 and miR-30d contributes to the development of anaplastic thyroid carcinoma targeting the polycomb protein EZH2. J. Clin. Endocrinol. Metab., 97(5):E710-E718. [doi:10.1210/jc.2011-3068]

Fagin, J.A., Mitsiades, N., 2008. Molecular pathology of thyroid cancer: diagnostic and clinical implications. Best Pract. Res. Clin. Endocrinol. Metab., 22(6):955-969. [doi:10.1016/j.beem.2008.09.017]

Felli, N., Fontana, L., Pelosi, E., et al., 2005. MicroRNAs 221 and 222 inhibit normal erythropoiesis and erythroleukemic cell growth via kit receptor down-modulation. PNAS, 102(50):18081-18086. [doi:10.1073/pnas.050621 6102]

Ferraz, C., Eszlinger, M., Paschke, R., 2011. Current state and future perspective of molecular diagnosis of fine-needle aspiration biopsy of thyroid nodules. J. Clin. Endocrinol. Metab., 96(7):2016-2026. [doi:10.1210/jc.2010-2567]

Frezzetti, D., Reale, C., Calì, G., et al., 2011a. The microRNAprocessing enzyme Dicer is essential for thyroid function. PLoS ONE, 6(11):e27648. [doi:10.1371/journal.pone. 0027648]

Frezzetti, D., de Menna, M., Zoppoli, P., et al., 2011b. Upregulation of miR-21 by Ras in vivo and its role in tumor growth. Oncogene, 30(3):275-286. [doi:10.1038/onc. 2010.416]

Galardi, S., Mercatelli, N., Giorda, E., et al., 2007. miR-221 and miR-222 expression affects the proliferation potential of human prostate carcinoma cell lines by targeting p27 Kipl. J. Biol. Chem., 282(32):23716-23724. [doi:10. 1074/jbc.M701805200]

Gallagher, W.M., Greene, L.M., Ryan, M.P., et al., 2001. Human fibulin-4: analysis of its biosynthetic processing and mRNA expression in normal and tumour tissues. FEBS Lett., 489(1):59-66. [doi:10.1016/S0014-5793(00) 02389-9]

Gao, Y., Wang, C., Shan, Z., et al., 2010. miRNA expression in a human papillary thyroid carcinoma cell line varies with invasiveness. Endocr. J., 57(1):81-86. [doi:10.1507/ endocrj.K09E-220]

Garofalo, M., Quintavalle, C., di Leva, G., et al., 2008. MicroRNA signatures of TRAIL resistance in human non-small cell lung cancer. Oncogene, 27(27):3845-3855. [doi:10.1038/onc.2008.6]

Garzia, L., Andolfo, I., Cusanelli, E., et al., 2009. MicroRNA199b-5p impairs cancer stem cells through negative regulation of HES1 in medulloblastoma. PLoS ONE, 4(3): e4998. [doi:10.1371/journal.pone.0004998] 
Gebeshuber, C.A., Zatloukal, K., Martinez, J., 2009. miR-29a suppresses tristetraprolin, which is a regulator of epithelial polarity and metastasis. EMBO Rep., 10(4): 400-405. [doi:10.1038/embor.2009.9]

Geraldo, M.V., Yamashita, A.S., Kimura, E.T., 2012. MicroRNA $m i R-146 b-5 p$ regulates signal transduction of TGF- $\beta$ by repressing SMAD4 in thyroid cancer. Oncogene, 31(15):1910-1922. [doi:10.1038/onc.2011.381]

Gharib, H., 2004. Changing trends in thyroid practice: understanding nodular thyroid disease. Endocr. Pract., 10(1): 31-39. [doi:10.4158/EP.10.1.31]

Gregory, P.A., Bracken, C.P., Bert, A.G., et al., 2008. MicroRNAs as regulators of epithelial-mesenchymal transition. Cell Cycle, 7(20):3112-3118.

Guo, C.J., Pan, Q., Li, D.G., et al., 2009. miR-15b and miR-16 are implicated in activation of the rat hepatic stellate cell: an essential role for apoptosis. J. Hepatol., 50(4):766-778. [doi:10.1016/j.jhep.2008.11.025]

He, H., Jazdzewski, K., Li, W., et al., 2005. The role of microRNA genes in papillary thyroid carcinoma. PNAS, 102(52):19075-19080. [doi:10.1073/pnas.0509603102]

Huang, Y., Shen, X.J., Zou, Q., et al., 2010. Biological functions of microRNAs: a review. J. Physiol. Biochem., 67(1):129-139. [doi:10.1007/s13105-010-0050-6]

Hurst, D.R., Edmonds, M.D., Scott, G.K., et al., 2009. Breast cancer metastasis suppressor 1 up-regulates miR-146, which suppresses breast cancer metastasis. Cancer Res., 69(4):1279-1283. [doi:10.1158/0008-5472.CAN-08-3559]

Jazdzewski, K., Murray, E.L., Franssila, K., et al., 2008. Common SNP in pre-miR-146a decreases mature miR expression and predisposes to papillary thyroid carcinoma. PNAS, 105(20):7269-7274. [doi:10.1073/pnas.080268 2105]

Knauf, J.A., Ma, X., Smith, E.P., et al., 2005. Targeted expression of $B R A F^{\mathrm{V} 600 \mathrm{E}}$ in thyroid cells of transgenic mice results in papillary thyroid cancers that undergo dedifferentiation. Cancer Res., 65(10):4238-4245. [doi:10.1158/ 0008-5472.CAN-05-0047]

Kondo, T., Ezzat, S., Asa, S.L., 2006. Pathogenetic mechanisms in thyroid follicular-cell neoplasia. Nat. Rev. Cancer, 6(4):292-306. [doi:10.1038/nrc1836]

Korpal, M., Kang, Y., 2008. The emerging role of miR-200 family of microRNAs in epithelial-mesenchymal transition and cancer metastasis. RNA Biol., 5(3):115-119.

Kota, J., Chivukula, R.R., O'Donnell, K.A., et al., 2009. Therapeutic microRNA delivery suppresses tumorigenesis in a murine liver cancer model. Cell, 137(6):1005-1017. [doi:10.1016/j.cell.2009.04.021]

$\mathrm{Ku}, \mathrm{G} ., \mathrm{McManus}, \mathrm{M} . \mathrm{T} ., 2008$. Behind the scenes of a small RNA gene-silencing pathway. Hum. Gene Ther., 19(1): 17-26. [doi:10.1089/hum.2007.1226]

Labbaye, C., Spinello, I., Quaranta, M.T., et al., 2008. A threestep pathway comprising PLZF/miR-146a/CXCR4 controls megakaryopoiesis. Nat. Cell Biol., 10(7):788-801. [doi:10.1038/ncb1741]

Landi, D., Gemignani, F., Landi, S., 2012. Role of variations within microRNA-binding sites in cancer. Mutagenesis, 27(2):205-210. [doi:10.1093/mutage/ger055]

Leone, V., D'Angelo, D., Rubio, I., et al., 2011. miR-1 is a tumor suppressor in thyroid carcinogenesis targeting CCND2, CXCR4, and SDF-1a. J. Clin. Endocrinol. Metab., 96(9):E1388-E1398. [doi:10.1210/jc.2011-0345]

Liu, X., Cheng, Y., Yang, J., et al., 2012. Cell-specific effects of miR-221/222 in vessels: molecular mechanism and therapeutic application. J. Mol. Cell. Cardiol., 52(1): 245-255. [doi:10.1016/j.yjmcc.2011.11.008]

Marini, F., Luzi, E., Brandi, M.L., 2011. MicroRNA role in thyroid cancer development. J. Thyroid Res., 2011: 407123. [doi:10.4061/2011/407123]

Mattie, M.D., Benz, C.C., Bowers, J., et al., 2006. Optimized high-throughput microRNA expression profiling provides novel biomarker assessment of clinical prostate and breast cancer biopsies. Mol. Cancer, 5(1):24. [doi:10. 1186/1476-4598-5-24]

Mazeh, H., 2012. MicroRNA as a diagnostic tool in fineneedle aspiration biopsy of thyroid nodules. Oncologist, 17(8):1032-1038. [doi:10.1634/theoncologist.2012-0013]

McHenry, C.R., Phitayakorn, R., 2011. Follicular adenoma and carcinoma of the thyroid gland. Oncologist, 16(5): 585-593. [doi:10.1634/theoncologist.2010-0405]

Menon, M.P., Khan, A., 2009. micro-RNAs in thyroid neoplasms: molecular, diagnostic and therapeutic implications. J. Clin. Pathol., 62(11):978-985. [doi:10.1136/jcp.2008. 063909]

Mian, C., Pennelli, G., Fassan, M., et al., 2012. MicroRNA profiles in familial and sporadic medullary thyroid carcinoma: preliminary relationships with RET status and outcome. Thyroid, 22(9):890-896. [doi:10.1089/thy. 2012.0045]

Mitomo, S., Maesawa, C., Ogasawara, S., et al., 2008. Downregulation of miR-138 is associated with overexpression of human telomerase reverse transcriptase protein in human anaplastic thyroid carcinoma cell lines. Cancer Sci., 99(2):280-286. [doi:10.1111/j.1349-7006. 2007.00666.x]

Mitsiades, C.S., Negri, J., McMullan, C., et al., 2007. Targeting $B R A F^{\mathrm{V} 600 \mathrm{E}}$ in thyroid carcinoma: therapeutic implications. Mol. Cancer Ther., 6(3):1070-1078. [doi:10. 1158/1535-7163.MCT-06-0449]

Murakami, Y., Yasuda, T., Saigo, K., et al., 2006. Comprehensive analysis of microRNA expression patterns in hepatocellular carcinoma and non-tumorous tissues. Oncogene, 25(17):2537-2545. [doi:10.1038/sj.onc.1209 283]

Nikiforov, Y.E., Nikiforova, M.N., 2011. Molecular genetics and diagnosis of thyroid cancer. Nat. Rev. Endocrinol., 7(10):569-580. [doi:10.1038/nrendo.2011.142]

Nikiforova, M.N., Tseng, G.C., Steward, D., et al., 2008. 
MicroRNA expression profiling of thyroid tumors: biological significance and diagnostic utility. J. Clin. Endocrinol. Metab., 93(5):1600-1608. [doi:10.1210/jc.20072696]

Nikiforova, M.N., Chiosea, S.I., Nikiforov, Y.E., 2009. MicroRNA expression profiles in thyroid tumors. Endocr. Pathol., 20(2):85-91. [doi:10.1007/s12022-009-9069-z]

Pallante, P., Visone, R., Croce, C.M., et al., 2010. Deregulation of microRNA expression in follicular-cell-derived human thyroid carcinomas. Endocr. Relat. Cancer, 17(1):91-104. [doi:10.1677/ERC-09-0217]

Ponta, H., Hofmann, M., Herrlich, P., 2001. Recent advances in the genetics of metastasis. Eur. J. Cancer, $\mathbf{3 0 A}(13)$ : 1995-2001.

Ricarte-Filho, J.C., Fuziwara, C.S., Yamashita, A.S., et al., 2009. Effects of let-7 microRNA on cell growth and differentiation of papillary thyroid cancer. Transl. Oncol., 2(4):236-241.

Schulte, K.M., Jonas, C., Krebs, R., et al., 2001. Activin A and activin receptors in thyroid cancer. Thyroid, 11(1):3-14. [doi:10.1089/10507250150500603]

Schwertheim, S., Sheu, S.Y., Worm, K., et al., 2009. Analysis of deregulated miRNAs is helpful to distinguish poorly differentiated thyroid carcinoma from papillary thyroid carcinoma. Horm. Metab. Res., 41(6):475-481. [doi:10. 1055/s-0029-1215593]

Shastry, B.S., 2009. SNPs: impact on gene function and phenotype. In: Komar, A.A. (Ed.), Single Nucleotide Polymorphisms. Springer, p.3-22. [doi:10.1007/978-1-60327411-1_1]

Sheu, S.Y., Grabellus, F., Schwertheim, S., et al., 2010. Differential miRNA expression profiles in variants of papillary thyroid carcinoma and encapsulated follicular thyroid tumours. Br. J. Cancer, 102(2):376-382. [doi:10. 1038/sj.bjc.6605493]

Shibru, D., Chung, K.W., Kebebew, E., 2008. Recent developments in the clinical application of thyroid cancer biomarkers. Curr. Opin. Oncol., 20(1):13-18. [doi:10. 1097/CCO.0b013e3282f27e49]

Taganov, K.D., Boldin, M.P., Chang, K.J., et al., 2006. $\mathrm{NF}-\kappa \mathrm{B}-$ dependent induction of microRNA miR-146, an inhibitor targeted to signaling proteins of innate immune responses. PNAS, 103(33):12481-12486. [doi:10.1073/ pnas.0605298103]

Takakura, S., Mitsutake, N., Nakashima, M., et al., 2008. Oncogenic role of miR-17-92 cluster in anaplastic thyroid cancer cells. Cancer Sci., 99(6):1147-1154. [doi:10. 1111/j.1349-7006.2008.00800.x]

Tetzlaff, M.T., Liu, A., Xu, X., et al., 2007. Differential expression of miRNAs in papillary thyroid carcinoma compared to multinodular goiter using formalin fixed paraffin embedded tissues. Endocr. Pathol., 18(3): 163-173. [doi:10.1007/s12022-007-0023-7]

Visone, R., Pallante, P., Vecchione, A., et al., 2007. Specific
microRNAs are downregulated in human thyroid anaplastic carcinomas. Oncogene, 26(54):7590-7595. [doi:10. 1038/sj.onc.1210564]

Vriens, M.R., Schreinemakers, J.M., Suh, I., et al., 2009. Diagnostic markers and prognostic factors in thyroid cancer. Future Oncol., 5(8):1283-1293. [doi:10.2217/fon.09.85]

Vriens, M.R., Weng, J., Suh, I., et al., 2012. MicroRNA expression profiling is a potential diagnostic tool for thyroid cancer. Cancer, 118(13):3426-3432. [doi:10.1002/cncr. 26587]

Wan, P.T., Garnett, M.J., Roe, S.M., et al., 2004. Mechanism of activation of the $R A F-E R K$ signaling pathway by oncogenic mutations of $B-R A F$. Cell, 116(6):855-867. [doi:10. 1016/S0092-8674(04)00215-6]

Wang, J., Wang, Q., Liu, H., et al., 2012. The association of miR-146a rs2910164 and miR-196a2 rs11614913 polymorphisms with cancer risk: a meta-analysis of 32 studies. Mutagenesis, 27(6):779-788. [doi:10.1093/mutage/ges052]

Weber, F., Teresi, R.E., Broelsch, C.E., et al., 2006. A limited set of human microRNA is deregulated in follicular thyroid carcinoma. J. Clin. Endocrinol. Metab., 91(9): 3584-3591. [doi:10.1210/jc.2006-0693]

Wellbrock, C., Karasarides, M., Marais, R., 2004. The RAF proteins take centre stage. Nat. Rev. Mol. Cell Biol., 5(11):875-885. [doi:10.1038/nrm1498]

Wlazlinski, A., Engers, R., Hoffmann, M.J., et al., 2007. Downregulation of several fibulin genes in prostate cancer. Prostate, 67(16):1770-1780. [doi:10.1002/pros. 20667]

Wojciechowska, K., Lewinski, A., 2006. BRAF mutations in papillary thyroid carcinoma. Endocr. Regul., 40(4): 129-138.

Xing, M., 2007. BRAF mutation in papillary thyroid cancer: pathogenic role, molecular bases, and clinical implications. Endocr. Rev., 28(7):742-762. [doi:10.1210/er. 2007-0007]

Xiong, Y., Zhang, L., Holloway, A.K., et al., 2011. miR-886$3 p$ regulates cell proliferation and migration, and is dysregulated in familial non-medullary thyroid cancer. PLoS ONE, 6(10):e24717. [doi:10.1371/journal.pone.0024717]

Yau, T., Lo, C.Y., Epstein, R.J., et al., 2008. Treatment outcomes in anaplastic thyroid carcinoma: survival improvement in young patients with localized disease treated by combination of surgery and radiotherapy. Ann. Surg. Oncol., 15(9):2500-2505. [doi:10.1245/s10434-0080005-0]

Yip, L., Nikiforova, M.N., Carty, S.E., et al., 2009. Optimizing surgical treatment of papillary thyroid carcinoma associated with BRAF mutation. Surgery, 146(6):1215-1223. [doi:10.1016/j.surg.2009.09.011]

Yip, L., Kelly, L., Shuai, Y., et al., 2011. MicroRNA signature distinguishes the degree of aggressiveness of papillary thyroid carcinoma. Ann. Surg. Oncol., 18(7):2035-2041. [doi:10.1245/s10434-011-1733-0] 
Yu, S., Liu, Y., Wang, J., et al., 2012. Circulating microRNA profiles as potential biomarkers for diagnosis of papillary thyroid carcinoma. J. Clin. Endocrinol. Metab., 97(6): 2084-2092. [doi:10.1210/jc.2011-3059]

Yue, C., Wang, M., Ding, B., et al., 2011. Polymorphism of the pre-miR-146a is associated with risk of cervical cancer in a Chinese population. Gynecol. Oncol., 122(1):33-37. [doi:10.1016/j.ygyno.2011.03.032]
Zhou, B., Wang, K., Wang, Y., et al., 2011. Common genetic polymorphisms in pre-microRNAs and risk of cervical squamous cell carcinoma. Mol. Carcinog., 50(7):499-505. [doi:10.1002/mc.20740]

Zhu, H., Wu, H., Liu, X., et al., 2009. Regulation of autophagy by a beclin 1-targeted microRNA, miR-30a, in cancer cells. Autophagy, 5(6):816-823.

\section{中文概要:}

\section{本文题目: 甲状腺肿瘤中 microRNA 表达失调的研究进展}

\section{Deregulation of microRNA expression in thyroid tumors}

研究目的：MicroRNAs（miRNAs 或 miRs）是一种内源性非编码 RNA，通过与信使 RNA（mRNA）的 3'非编码区结合, 引起 mRNA 的断裂或蛋白质翻译的阻断, 进而对基因表达进行负性调控。 miRNAs 可影响细胞的分化、增殖和生存等过程, 其表达失调有引起疾病甚至肿瘤的可能。 miRNA 表达失调已在多种人类肿瘤中出现, 包括甲状腺肿瘤。本文对不同类型的甲状腺肿 瘤中出现的 miRNAs 表达失调及 miRNAs 可能的下游靶基因进行综述, 为甲状腺肿瘤的临床 诊断及治疗提供依据。

创新要点: 已有大量关于滤泡细胞起源, 尤其是乳头状甲状腺癌（PTC）中 miRNAs 表达失调的综述, 但对 C 细胞起源的甲状腺髓样癌 (MTC) 中 miRNAs 表达失调的研究并未形成系统。同时, 在此之前没有关于各型甲状腺肿瘤 miRNAs 表达与其靶基因的综述报道。在这篇综述中，我 们还列入了对甲状腺肿瘤患者外周循环血液中 miRNAs 表达谱的最新研究以及单核苷酸多态 性（SNP）对甲状腺肿瘤的影响。

重要结论: 总结了 miRNAs 在各型甲状腺肿瘤中的表达谱（见表 $1 、 3 、 4 、 6$ ）; 描述了在各型甲状腺肿 瘤中不同 miRNAs 潜在的靶基因及其在肿瘤发生、发展、浸润、转移等多方面的作用（见 图 1; 表 2、5）。

关键词组: MicroRNA; 靶基因; 甲状腺肿瘤; 单核苷酸多态性; 体细胞突变 